\title{
PENELITIAN TERHADAP STRUKTUR CERITA, KONTEKS, KO-TEKS, PROSES PEWARISAN, FUNGSI, NILAI-NILAI, DAN ANCANGAN MODEL REVITALISASI TRADISI LISAN JEMBLUNG JAWA TIMUR
}

\author{
Peni Puspitasari
}

E-mail: penipuspitasari89@yahoo.com

\begin{abstract}
ABSTRAK
Penelitian ini dilatarbelakangi oleh asumsi bahwa tradisi lisan Jemblung merupakan tradisi lisan yang dapat diapresiasi sebagai sebuah kesenian yang hampir punah padahal kaya akan nilai-nilai luhur yang dapat dimanfaatkan baik untuk pendidikan formal maupun nonformal. Metode yang digunakan dalam penelitian ini adalah deskriptif kualitatif. Instrumen dalam penelitian ini adalah peneliti sendiri dengan menggunakan pedoman wawancara dan catatan lapangan. Temuan dalam penelitian ini meliputi: (1) struktur cerita dalam tradisi lisan jemblung, yang diklasifikasikan dalam alur, tokoh dan penokohan, dan latar, (2) aspek konteks yang meliputi konteks budaya, sosial, situasi, dan ideologi, (3) ko-teks dalam tradisi lisan jemblung diklasifikasikan dengan konsep antropolinguistik, meliputi: (a) deskripsi paralinguistik, (b) gestur (c) penjagaan antarpelaku, dan (d) unsur material: pakaian, penataan lokasi dan dekorasi, penggunaan properti dan fungsinya, (4) proses pewarisan dalam tradisi lisan jemblung ini dibagi menjadi dua yakni proses menjadi pemain dan proses penciptaan cerita, (4) fungsi tradisi lisan jemblung sebagai berikut: (a) alat pengesahan kebudayaan, (b) pemaksa berlakunya norma di masyarakat, (c) alat pendidikan, (d) hiburan (e) Media dakwah, dan (f) media propaganda tematik. Nilai-Nilai yang ditemukan dalam tradisi lisan Jemblung didominasi oleh nilai religi dan nilai budaya.
\end{abstract}

Kata kunci: tradisi lisan jemblung, struktur cerita, konteks, ko-teks, proses pewarisan, fungsi, nilai, ancangan revitalisasi.

\section{ABSTRACT}

The research entitled "A reasearch about structure of story, Context, Co-text, The Process of Inheritance, Functions, Values, and The plan of revitalization models of Oral Tradition Jemblung Jawa Timur" was backgrounded by assumption that oral tradition jemblung is oral tradition which can be appreciated as one of glorious art that almost extinct whereas has many of values for formal or informal education. The method used in this research is descriptive qualitative. The instrument in this study is the researchers themselves using guidance interviews and field notes. The technique of this study using the technique of direct data collection from the field when the show takes place. Analysis of the data in this study are based on interviews and observations, as well as recording and interpretation of field notes. The findings in this study include: (1) the structure of stories in the oral tradition Jemblung, (2) aspects of context that includes cultural, social, situation, and ideology. From the aspect of context, it can be concluded that the performance Jemblung in this study in the context of marriage. (3) co-text in oral tradition Jemblung classified antropolinguistik concept, include: (a) a description of paralinguistic, (b) gestures (c) actor custody, and (d) the material elements: the clothes, the location and arrangement of the decoration, the use of properties and functions, (4) the process of inheritance in Jemblung oral tradition is divided into two processes into the player and the story creation process, (4) the function of the oral tradition as follows Jemblung. Values are found in the oral traditions Jemblung dominated by religious values and cultural values.

Key words: oral tradition jemblung, structure of story, context, co-text, process of inhearing, function, values, The plan for revitalizartion. 


\section{PENDAHULUAN}

Indonesia merupakan Negara yang kaya akan tradisi lisan di setiap wilayahnya. Tradisi lisan yang merupakan identitas kultural dan mengandung nilai-nilai luhur yang masih relevan dengan zaman sekarang. Pada saat ini, tradisi lisan di Indonesia masih terus menggeliat di berbagai wilayah meski samar-samar dan bahkan beberapa di antaranya telah meredup dan mati. Banyak generasi muda bahkan generasi tua yang sudah tidak mengenal lagi tradisi lisan yang terdapat di daerahnya. Di Indonesia, kajian akademis yang serius mengenai tradisi lisan baru dewasa ini bangkit dengan digawangi hadirnya Asosiasi Tradisi Lisan.

Menurut Sibarani (2010:12) penyebab hilangnya sebuah tradisi atau kebudayaan disebabkan oleh hal-hal berikut. (1) Pemahaman bahwa tradisi adalah masa lalu dan kuno yang tidak perlu untuk masa kini apalagi untuk masa mendatang, (2) modernitas dianggap satu-satunya jalan untuk kemajuan suatu bangsa sehingga orang mengejar modernitas tanpa menghiraukan tradisi budayanya, (3) modernitas melakukan perubahan pada tradisi dan sekaligus 'mematikan' tradisi itu jika tidak sesuai dengan modernitas seperti peran agama yang baru dianut komunitas, (4) pemerintah dan elite politik tidak mampu memahami paradigma keberlanjutan atau kesinambungan tradisi budaya dari tradisi masa lalu ke masa kini dan meningkatkan kesejahteraan bangsa melalui penanaman nilai budaya dan penciptaan industri budaya. Semua hal tersebut menyebabkan hilangnya fungsi estetis dan fungsi etis sebuah tradisi.

Salah satu tradisi lisan yang terdapat di Jawa Timur adalah tradisi lisan jemblung. Tradisi lisan jemblung berwujud pertunjukan rakyat. Meskipun bernama sama, yakni jemblung, tradisi lisan jemblung Jawa Timur-an dan kesenian jemblung Banyumasan atau jemblung
Jawa Tengah berbeda dari segi pakem. Seni jemblung Banyumas berwujud pementasan seperti wayang orang atau ketoprak. Sementara tradisi lisan jemblung Jawa Timur-an merupakan seni bercerita yang dibawakan oleh seorang tukang cerita (dalang) dan dibantu oleh beberapa orang panjak (penabuh gamelan) yang menabuh alat-alat musik tradisional Jawa yang menjadi penanda kesenian ini. Terkadang dalang juga memainkan beberapa wayang (dari kulit) sebagian media pendukung. Tradisi lisan jemblung pada dasarnya menampilkan cerita-cerita yang bersumber dari cerita Menak atau bertema keagamaan (Islam). Namun pada zaman sekarang telah lebih banyak disesuaikan dengan kehidupan sehari-hari masyarakat tempat pertunjukan jemblung dipentaskan.

Sebagai salah satu kekayaan budaya daerah, tradisi lisan jemblung merupakan pertunjukan rakyat yang potensial di daerah aliran sungai Brantas Jawa Timur (Blitar, Kediri, Tulungagung,Ponorogo, Madiun, dan sekitarnya) yang bila dikemas dengan baik bisa menjadi aset pariwisata yang handal. Seni jemblung juga memiliki fungsi dan nilai-nilai luhur yang dapat dimanfaatkan sebagai pendidikan karakter.

Seperti nasib sebagian besar kesenian tradisional yang lain, tradisi lisan jemblung juga mengalami nasib yang memprihatinkan. Berdasarkan studi lapangan yang dilakukan oleh peneliti, tercatat bahwa kesenian ini sudah jarang dipentaskan. Ada beberapa faktor penyebab, yang pertama adalah sudah jarangnya masyarakat yang mengenal seni jemblung sehingga jarang ada masyarakat yang dengan sengaja mengundang dalang jemblung untuk memeriahkan hajatan dan acara lainnya. Faktor yang kedua adalah minimnya regenerasi dalang jemblung.

Di Blitar Jawa Timur, pada tahun 2013 
bahkan tercatat hanya terdapat dua orang dalang jemblung, dan tinggal satu orang saja yang masih hidup sampai sekarang. Begitu pula di kota-kota lain sekitar aliran sungai Brantas, pewaris jemblung terhitung satu atau dua kelompok saja.

Jika dahulu masih terdapat tukang kentrung maupun jemblung yang ngamen, maka sekarang tidak lagi. Panggilan tanggapan pun sudah jarang. Hal ini berkaitan erat dengan proses kemelekhurufan bangsa kita dan kemajuan media elektronik. Seiring dengan berkurangnya jumlah penduduk yang buta huruf, dan bertambahnya jumlah penduduk yang melek huruf, maka tradisi lisan pun semakin ditinggalkan oleh pendukungnya. Di samping itu, media elektronik, seperti radio dan televisi, yang memberikan hiburan dan informasi secara mudah dan murah, sudah dapat dinikmati oleh penduduk yang terpencil, jauh dari kota. Pertunjukan jemblung hanya dipentaskan jika ada permintaan dari pemerintah setempat dalam acara tertentu, atau permintaan dari masyarakat untuk hajatan yang jarang terjadi.

Pertunjukan jemblung sebagai salah satu dari bentuk tradisi lisan tidak luput dari kondisi tersebut. Perlu penanganan serius dan segera, karena sebagai aset budaya bangsa pertunjukan jemblung memiliki peran yang berarti bagi bangsa maupun bagi masyarakat pendukungnya. Berdasarkan hal tersebut di atas, penelitian ini dilakukan dengan harapan dapat mendeskripsikan struktur, konteks, ko-teks, proses pewarisan, fungsi, nilai dan sekaligus ancangan model revitalisasinya.

Sepengetahuan peneliti, beberapa penelitian terdahulu yang senada dengan penelitian ini adalah: (1) penelitian terhadap kentrung Sarahwulan oleh Suripan Sudi Hutomo (1987) yang meneliti tentang kentrung sarahwulan sebagai sastra lisan, (2) Modifikasi Seni Jemblung Ponorogo oleh Darni (2010) yang meneliti perubahan seni jemblung zaman dahulu dengan sekarang dan membuat rancangan modifikasi seni jemblung agar lebih relevan dengan zaman sekarang, (3) Seni Jemblung Murtadho dari Desa Tunjung Kajian Etnomusikologi oleh Prabowo (2012) meneliti aspek-aspek karawitan dalam jemblung, (4) Transformasi Pertunjukan Kesenian Jemblung "Putra Budaya" di dusun Kemuning Kelurahan Lirboyo Kecamatan Mojoroto Kota Kediri oleh Mohammad Syaiful Ali (2009) yang meneliti tentang perubahan-perubahan yang terjadi dalam perkembangan seni jemblung "Putra Budaya" di dusun Kemuning, (5) Nilai-nilai Pembangunan Masyarakat Desa Dalam Kesenian Jemblung Di Desa Tunjung Kecamatan Udanawu Kabupaten Blitar oleh Rahmawati yang meneliti aspek nilai pembangunan dalam jemblung (2008), dan Bahasa dalam wayang Jemblung di Kabupaten Tulungagung oleh Effendi (2010) yang memaparkan jenis-jenis bahasa yang digunakan dalam jemblung. Dari paparan di atas dapat diketahui bahwa belum ada penelitian yang memaparkan tradisi lisan jemblung secara holistik dan komprehensif meliputi struktur, konteks, ko-teks, proses pewarisan, fungsi, nilai-nilai, dan ancangan revitalisasi dalam sebuah penelitian yang utuh. Hal ini yang menjadi titik perbedaan penelitian ini dengan penelitian terdahulu.

\section{METODE}

Metode yang digunakan dalam penelitian ini adalah deskriptif kualitatif. Instrumen dalam penelitian ini adalah peneliti sendiri dengan menggunakan pedoman wawancara dan catatan lapangan. Adapun teknik penelitian ini menggunakan teknik pengumpulan data langsung dari lapangan ketika pertunjukan berlangsung. Analisis data dalam penelitian ini didasarkan pada hasil wawancara dan observasi, serta penginterpretasian terhadap rekaman dan catatan lapangan. 


\section{HASIL PENELITIAN DAN PEMBAHASAN}

\section{A. Pembahasan Konteks Budaya}

Tradisi lisan jemblung dilaksanakan dalam berbagai acara adat seperti hajatan pernikahan, hajatan khitanan, bersih desa, perayaan Agustusan, tasyakuran, dst. Pada penelitian ini tradisi lisan jemblung dilaksanakan sebagai salah satu rangkaian acara pernikahan. Lebih tepatnya termasuk salah satu rangkaian acara ruwatan pernikahan. Dalam budaya Jawa, ruwatan merupakan sarana pembebasan dan penyucian manusia atas dosanya/ kesalahannya yang berdampak kesialan didalam hidupnya. Ada beberapa syarat yang mengharuskan seseorang diruwat agar tidak mengalami kesialan. Dalam budaya Jawa biasa disebut janma sukerta yaitu manusia yang karena sesuatu hal (menyandang sukerta), menjadikan hidupnya sering atau selalu mendapat kesialan ( celaka, menderita, apes dst). Ada beberapa manusia yang tergolong janma sukerta dan harus diruwat, salah satunya adalah anak ontang-anting yaitu anak tunggal, baik laki-laki maupun perempuan. Pada penelitian ini janma sukerta adalah Mohammad Sholeh, anak tunggal (ontang-anting) Ibu Poniyem. Jadi tradisi lisan jemblung dalam konteks ini merupakan bagian dari serangkaian acara pernikahan sekaligus ruwatan dan merupakan sebuah bentuk rasa syukur yang bersifat menghibur.

Ketika pertunjukan berlangsung, keluarga yang mengadakan hajatan menyediakan tempat di halaman rumahnya dan makanan yang berupa makanan khas sajian untuk hajatan pernikahan, yakni jenang merah, jadah, lemper, pisang mentah, pisang goreng, dan kerupuk, juga air mineral. Berkenaan makanan ini sangat bergantung pada tingkat perekonomian keluarga pemilik hajatan. Keluarga yang mengadakan hajatan meminta bantuan kepada para pemuda desa untuk mengamankan pertunjukan.

Pertunjukan jemblung dilaksanakan sebelum/setelah rangkaian acara pernikahan dimulai. Pesta pernikahan dalam adat Jawa, khususnya Blitar, Kediri, Tulungagung dan sekitarnya dapat dilaksanakan dalam waktu 3 hari berturut-turut, di mana dibedakan sesuai urutan yakni: manggulan (kondangan), ijaban (akad nikah), temu (temu pengantin), walimah/resepsi. Pada penelitian ini pertunjukan jemblung dilakukan saat manggulan, yakni ketika para tamu undangan datang untuk buwuh (kondangan). Para tamu hadir sekaligus untuk menyaksikan pertunjukan jemblung.

Seluruh pemain datang dalam satu rombongan sekitar satu-dua jam sebelum pertunjukan dimulai. Sebelum melakukan persiapan, seluruh kru pemain menemui pemilik rumah layaknya bertamu, untuk memperkenalkan diri dan pada saat itu pula biasanya terjadi transaksi pemberian honor dan pemberian mahar berupa pakaian sholat lengkap oleh pemilik rumah kepada dalang. Oleh dalang kemudian mahar tersebut diserahkan pada pesantren atau masjid. Dalam konteks pernikahan, pihak kelompok pemain juga memberikan kado atau hadiah yang isinya bebas, untuk pengantin. Setelah perkenalan, seluruh kru pemain dijamu oleh tuan rumah dengan makanan dan kue-kue khas pesta pernikahan. Selesai acara makan-makan, seluruh kru pemain melakukan persiapan dengan cek sound dan peletakan seluruh keperluan panggung. Para pemain juga berganti pakaian dengan seragam kelompok kesenian jemblung Murtadho. Setelah semua siap baru pertunjukan dimulai.

Pertunjukan jemblung dipilih sebagai hiburan karena dianggap cukup terjangkau yakni Rp 3.500.000 dalam sekali pertunjukan, dibandingkan pertunjukan lain yang biasa digunakan dalam perayaan pernikahan, seperti pertunjukan wayang kulit yang bisa mencapai angka ratusan juta rupiah dalam satu kali pertunjukan. Terutama bagi penanggap yang berasal dari kalangan sosial masyarakat menengah ke bawah. Selain itu, 
pertunjukan jemblung dipandang sebagai pertunjukan yang sangat merakyat terutama dalam aspek bahasa sehingga dapat dijangkau dan menghibur semua kalangan terutama kalangan awam.

Isi cerita yang dibawakan dalam pertunjukan jemblung juga disesuaikan dengan konteks yang melatarbelakanginya. Pada penelitian ini dalam konteks ruwatan dan pernikahan, maka cerita yang dipilih bersumber dari Babad Tanah Jawi dalam episode Syeich Syubakir numbali tanah Jawa. Dalam cerita 'Syeich Syubakir Menumbali Tanah Jawa', diceritakan bahwa Bathara Kala hendak mencari mangsa janma sukerta, yakni orang yang menyandang kesialan, salah satunya adalah anak ontang-anting. Dalam cerita disisipkan konteks riil sesuai tujuan pertunjukan yakni ngruwat, maka diceritakan bahwa Bathara Kala tidak mendapatkan mangsa karena si anak ontang-anting Mohammad Sholeh (si pemilik hajatan) telah diruwat sehingga selamat dari mangsa Bathara Kala.

Sesuai dengan konteks pertunjukan yakni dalam rangkaian acara pernikahan dan jemblung sendiri merupakan kesenian Jawa Islami, maka disisipkan pula nasihat-nasihat tentang hukum-hukum dalam Islam terkait pernikahan yang dibalut dalam guyonan. Ajaran-ajaran ini disisipkan baik dalam bentuk lagu maupun senggakan (interaksi) antara dalang dengan para panjak maupun dengan penonton. Dalam hal ini diksi yang digunakan dan tema-tema wejangan yang dipilih sangat sesuai dengan konteks riil pengalaman masyarakat sehari-hari. Terjadi perkawinan antara nilai tradisional dan nilai modern dalam memandang hukum-hukum pernikahan

Selain berisi hukum pernikahan dalam Islam, teks dalam pertunjukan juga berisi segala filosofi dari berbagai makanan, benda, atau rangakain prosesi dalam sebuah prosesi pernikahan.
Selain dalam konteks pernikahan, tradisi lisan jemblung dalam penelitian ini juga merupakan bagian dari prosesi ruwatan sehingga menggunakan cerita dari babad Tanah Jawa episode Syeich Syubakir menumbali tanah Jawa. Dalam cerita dikisahkan bahwa Syeich Syubakir menumbali tanah Jawa dengan tujuan agar tanah Jawa dapat ditinggali oleh manusia. Usaha ini akan digagalkan oleh Bathara Kala, karena Bathara Kala menginginkan manusia untuk menjadi mangsanya, terutama Mohammad Soleh (pengantin laki-laki yang merupakan anak dari penanggap (pemilik hajat) karena Mohammad Soleh memenuhi syarat-syarat penyandang sukerta. Tetapi kenyataannya Bathara Kala tidak akan mampu memangsa Mohammad Soleh karena tanah Jawa telah ditumbali oleh Syeich Syubakir, sehingga Mohammad Soleh dan keluarganya akan selamat selamanya

Dari hasil analisis konteks budaya dapat disimpulkan bahwa tradisi lisan jemblung hidup dalam masyarakat Jawa, khususnya Jawa Timur. Tradisi Lisan jemblung merepresentasikan unsur-unsur budaya masyarakat Jawa Timur baik pada masa lampau maupun pada masa sekarang. Tradisi lisan jemblung sesuai dengan karakter orang Jawa yang cenderung menyampaikan segala sesuatu tidak secara terus terang namun lebih menggunakan metafora. Dalam hal ini tradisi lisan jemblung dimanfaatkan untuk menyampaikan dakwah atau tujuan lain yang terbungkus dalam pertunjukan.

\section{B. Pembahasan Konteks Sosial}

Analisis terhadap konteks sosial berdasarkan pada teori Sibarani (2012) yang mengacu pada faktor-faktor sosial yang mempengaruhi teks mencakup perbedaan jenis kelamin,stratifikasi sosial, perbedaan kelompok etnik, perbedaan tempat, perbedaan tingkat pendidikan, perbedaan usia, dst.

Berdasarkan analisis terhadap konteks sosial yang telah dipaparkan pada bagian 
deskripsi data, dapat disimpulkan bahwa tradisi lisan jemblung dalam penelitian ini dimainkan oleh kelompok kesenian jemblung "Sadat Sawedhar" dari desa Tunjungan, kecamatan Udanawu, Kabupaten Blitar. Pemain kesenian ini terdiri dari berbagai profesi yang heterogen, namun sebagian besar bermata pencaharian sebagai petani sebagai mata pencaharian utama. Usia pemain dikelompokkan menjadi dua, yakni golongan tua dan golongan muda. Golongan tua menduduki peran sebagai pemain inti, sementara golongan muda yang jumlahnya relatif lebih sedikit menduduki peran pemain tambahan. Hal ini dapat dijadikan alasan betapa pentingnya regenerasi pemain kesenian jemblung.

Dari aspek audiens, pada penelitian ini audiens relatif cukup banyak berjumlah 150 orang. Diasumsikan cukup banyak karena mengingat waktu pertunjukan yang malam hari dan konteks pertunjukan yang merupakan bagian dari hajatan personal biasanya tidak terlalu mengundang banyak audiens, disebabkan rasa segan audiens jika bukan undangan. Dengan kata lain, pertunjukan meskipun boleh saja disaksikan oleh umum, masih bersifat personal seperti klasifikasi Finnegan (1992:100).

Masih berdasarkan klasifikasi Finnegan (1992:98) audiens dalam pertunjukan jemblung pada penelitian ini dapat diklasifikasikan sebagai berikut: (a) Audiens utama dan audiens sampingan. Audiens utama merupakan mereka yang benar-benar datang untuk melihat pertunjukan, sementara audiens sampingan adalah para peneliti yang bertujuan untuk merekam dan meneliti pertunjukan, (b) Audiens merupakan audiens accidental (kebetulan). Audiens datang pada malam yang terbuka untuk menghadiri undangan pernikahan sekaligus menonton pertunjukan, (c) Audiens bersifat homogen berdasarkan latar belakang usia, pendidikan, dan pekerjaan.
Pertunjukan jemblung berlangsung lebih kurang 4 jam. Hal ini relatif lama dan sangat memungkinkan audiens menjadi bosan. Audiens yang bertahan menyaksikan pertunjukan hingga selesai mayoritas adalah audiens golongan tua, artinya sudah berusia di atas 50 tahun. Sementara audiens yang berusia muda justru banyak yang pulang sebelum pertunjukan berakhir. Hal ini dapat dijadikan sorotan untuk revitalisasi pertunjukan jemblung agar lebih menarik dan tidak membosankan bagi sebagian audiens.

Dari aspek penanggap (pemilik hajatan), penanggap dalam penelitian ini adalah seorang perempuan berusia 48 tahun yang berstatus janda. Namun meskipun janda, ibu Poniyem merupakan kalangan yang cukup mampu. Dapat disimpulkan bahwa penanggap pertunjukan jemblung jika merupakan penanggap pribadi (bukan kelompok/instansi) pada umumnya adalah orang yang secara ekonomi menengah atau menengah ke atas. Meski tidak menutup kemungkinan jika kalangan menengah ke bawah juga mampu menanggap kesenian ini.

Dari pembahasan terhadap ketiga aspek tersebut dapat disimpulkan bahwa tradisi lisan jemblung hidup dalam konteks sosial masyarakat Jawa Timur dengan berbagai latar belakang yang berbeda. Baik dari aspek usia, tingkat pendidikan, dan latar belakang sosial lainnya. Dengan kata lain, jemblung dapat dinikmati oleh semua kalangan, baik anakanak maupun dewasa, baik kalangan mampu maupun yang kurang mampu. Adapun karena jemblung merupakan kesenian Jawa Islami, maka sasarannya memang untuk orang Islam karena dari segi isi didominasi oleh ajaranajaran Islam. Meski tidak ada larangan bagi agama lain untuk menyaksikan atau menanggap kesenian ini.

\section{Pembahasan Konteks Situasi}

Analisis terhadap konteks sosial berdasarkan pada teori Sibarani (2012: 325) yang mengacu pada waktu, tempat, dan penggunaan teks. 
Berdasarkan analisis terhadap konteks situasi dapat diketahui bahwa pertunjukan jemblung ini terorganisasi dan terencana. Pertunjukan dalam situasi informal dan dilaksanakan pada malam hari. Di rumah Ibu Poniyem dalam rangka berbahagia meruwat putra semata wayangnya yang sedang melangsungkan pernikahan.

Selain berdasarkan pendapat Sibarani, analisis juga didasarkan pada teori Finnegan (1992: 101) yang menyebutkan aspek sikap penonton penting juga untuk diteliti. Pada penelitian ini penonton nampak antusias. Asumsi ini dibuktikan dengan daya tahan penonton untuk tetap menyaksikan pertunjukan hingga pertunjukan selesai, meski jumlahnya terus berkurang.

\section{Pembahasan Konteks Ideologi}

Analisis terhadap konteks Ideologi berdasarkan pada teori Sibarani (2012) yang mengacu pada kekuasaan atau kekuatan yang mendominasi isi teks. Pertunjukan jemblung merupakan kesenian Jawa Islami yang bermuatan hukum-hukum Islam. Dakwah yang dikemas dalam kesenian. Ideologi religi yang melatarbelakangi tentu saja adalah agama Islam baik Islam santri maupun Islam abangan, dan dalam konteks budaya Jawa sesuai keseharian hidup orang Jawa.

Selain ideologi religi, ideologi politik juga ditemukan dalam pesan-pesan pertunjukan jemblung. Pesan yang berisi teladan menjadi seorang pemimpin rakyat. Juga pesan bagaimana menjadi pemimpin yang amanah sesuai ajaran Islam.

\section{E. Pembahasan Ko-Teks dalam Tradisi Lisan Jemblung}

Analisis Ko-teks dalam tradisi lisan jemblung mengacu pada Sibarani (2012) yang mengklasifikasikan ko-teks tradisi lisan dalam konsep antropolinguistik, meliputi: (a) deskripsi paralinguistik, (b) gesture (c) penjagaan antarpelaku, dan (d) Unsur material: pakaian, penataan lokasi dan dekorasi, penggunaan properti dan fungsinya, dan berdasarkand ata lapangan ditambahkan satu aspek lagi yakni lagu.

Analisis terhadap ko-teks dalam tradisi lisan jemblung berfungsi untuk memperjelas pesan atau makna yang ingin disampaikan dalam tradisi lisan jemblung. Deskripsi paralinguistik meliputi intonasi, aksen, jeda, tekanan menunjukkan lagu/irama dalang dalam bercerita dengan tujuan tertentu. Apakah sedang menasihati, mengkritik, menyindir, humor,dst. Begitu juga dengan analisis gesture, meski tidak terlampau banyak gesture dalam pertunjukan jemblung, dapat dilihat ekspresi dalang saat membawakan adegan tertentu memperjelas pesan.

Deskripsi mengenai penjagaan jarak antar pelaku memberikan memberikan interpretasi bahwa antarpelaku (pemain) memiliki blocking yang jelas. Dalang sebagai pusat pemain memiliki posisi utama yakni di tengah panggung bagian depan. Panjak berada di sekitar dalang dengan jarak tertentu. Sementara jarak antara pemain dengan audiens beberapa meter di depan, samping kanan, dan samping kiri panggung.

Analisis unsur material dalam pertunjukan Jemblung pada penelitian ini meliputi: pakaian, penataan lokasi dan dekorasi, penggunaan properti dan fungsinya. Dari aspek pakaian, pertunjukan jemblung tergolong menggunakan kostum yang sederhana.Pakaian parapemainmenggunakan seragam berupa kemeja putih dan celana kain warna gelap, sementara pakaian audiens bebas rapi layaknya menghadiri sebuah pesta pernikahan. Penataan lokasi dan dekorasi juga tergolong sederhana. Panggung terbuat dari kayu dan bersifat tidak permanen. Tidak ada hiasan-hiasan di panggung atau kelir seperti layaknya wayang purwa.

Beberapa properti tambahan digunakan selain memiliki fungsi tertentu juga memiliki makna tertentu. Alat musik inti yang berjumlah 
enam buah memiliki makna filosofis tertentu sehingga tidak hanya berfungsi sebagai alat musik saja. Begitu juga dengan penggunaan kupat luwar yang bermakna simbolik sebagai media pelepas segala kesedihan dan kecelakaan. Wayang yang digunakan hampir sama fungsinya dengan wayang purwa, yakni sebagai alat peraga. Meski jumlah wayang tidak selengkap seperti dalam wayang purwa.

Dapat disimpulkan bahwa ko-teks sangat mendukung jalannya pertunjukan dalam membangun suasana dan mempertegas pesan yang diusung dalam pertunjukan.

\section{F. Pembahasan Proses Pewarisan dalam Tradisi Lisan Jemblung}

Analisis terhadap proses pewarisann dalam tradisi lisan jemblung ini dibagi menjadi dua yakni proses menjadi pemain dan proses penciptaan cerita. Proses menjadi pemain dalam pertunjukan jemblung dapat dilakukan secara vertikal maupun horizontal. Proses menjadi pemain pada penelitian ini pun demikian, beberapa pemain mengalami proses vertikal, dan sebagian lain mengalami proses horizontal.

Proses secara horizontal diasumsikan karena terputusnya mata rantai pewarisan dari generasi ke generasi seiring perkembangan zaman. Para pemain senior tidak memiliki regenerasi sehingga terputuslah proses pewarisan tersebut. Sehingga para pemain baru yang ingin mempelajari kesenian jemblung belajar secara otodidak berdasarkan rekaman pertunjukan terdahulu.

Sementara proses penciptaan cerita dalam penelitian ini sudah tidak murni dari cerita Menak, melainkan dari babad tanah Jawa yang diolah dengan kreativitas dalang sesuai dengan tujuan dan konteks pertunjukan. Berdasarkan wawancara dengan dalang pada penelitian ini, diperoleh keterangan bahwa proses penciptaan cerita oleh dalang dilakukan dengan cara horizontal, yakni mempelajari cerita-cerita dari rekaman pertunjukan terdahulu, dan mempelajari cerita gubahan dalang terdahulu yang telah dibukukan.

\section{G. Pembahasan Fungsi dalam Tradisi Lisan Jemblung}

Berdasarkan analisis secara keseluruhan ditemukan empat fungsi tradisi lisan jemblung yang sesuai dengan teori fungsi tradisi lsian pada umumnya, yakni sebagai alat pengesahan kebudayaan, pemaksa berlakunya norma di masyarakat, alat pendidikan, dan hiburan. Dari semua fungsi tersebut fungsi hiburanlah yang menjadi muaranya. Tradisi lisan jemblung memiliki peran sebagai hiburan bagi masyarakat pemiliknya. Fungsi tersebut linier dengan klasifikasi fungsi folklor oleh Bascom dan Hutomo (1991:69).

Selain kelima fungsi yang telah diklasifikasikan sesuai dengan pendapat para ahli, berdasarkan temuan di lapangan ditemukan fungsi lain dalam tradisi lisan jemblung yakni sebagai media dakwah karena tradisi lisan jemblung merupakan kesenian Jawa Islami, sebagai media propaganda tematik yang dapat dimasuki propaganda di bidang apapun, dan sebagai ritual tertentu yang dalam penelitian ini merupakan bagian dari rangkaian ritual ruwatan.

Berdasarkan analisis terhadap fungsi tradisi lisan jemblung yang sangat potensial, penting sekali untuk diadakan upaya pelestarian/ revitalisasi terhadap kesenian ini yang akan dipaparkan pada bab berikutnya.

\section{H. Pembahasan Nilai}

Analisis nilai dalam penelitian ini dibatasi pada nilai budaya dan nilai religi. Hal ini karena kedua nilai inilah yang menonjol ditemukan baik dalam teks, konteks, maupun ko-teks tradisi lisan jemblung.

Jika dikaitkan dengan kerangka Kluckhohn mengenai nilai budaya, maka nilai-nilai budaya dalam jemblung juga mencakup kategori-kategori tersebut, yakni berikut paparannya. 
(1) Masalah universal mengenai hakekat hidup yang tercermin dalam nilai-nilai sebagai berikut: (a) tradisi ruwatan sebagi pembersih diri, (b) konsep bala kiwa bala tengen dalam wayang (golongan kanan dan golongan kiri), dan (c) peribahasa bathok bolu isi madu yang merupakan sifat dari tokoh Semar (d) petuah-petuah mengenai hakikat hidup yang disampaikan dengan metafor yang halus.

(2) Hakikat karya dan etos kerja, tercermin dalam nilai-nilai sebagai berikut: (a) harapan agar kedua mempelai kuat dalam mengarungi rumah tangga disimbolkan dalam kuwade (pelaminan), (b) ritual melempar daun sirih pada prosesi pernikahan bermakna bahwa daun sirih baik terjatuh dengan telentang atau telungkup, jika digigit akan sama saja rasanya dan nilai dalam prosesi menuangkan tilam lupus oleh pengantin laki-laki ke pangkuan pengantin perempuan pada saat temu pengantin, yang dipaparkan maknanya oleh dalang sebagai perjanjian soal nafkah antara suami dengan istri.

(3)Persepsi manusia tentang waktu, tercermin dalam nilai (a) pamali (larangan) memotong bambu di tengah hari, dan (b) pemilihan waktu pertunjukan jemblung yang berada sebelum manggulan .

(4) Pandangan manusia terhadap alam tercermin dalam kewajiban mengikat bambu yang telah dipotong-potong karena akan menjadi sandungan Bathara Kala dan (b) Syeich Syubakir berjuang menumbali tanah Jawa agar tanah Jawa dapat dihuni manusia dan manusia dapat bercocok tanam.

(5) Hakikat hubungan manusia dengan sesamanya tercermin dalam nilai sebagai berikut: (a) ritual unik ketika ada orang yang melahirkan, dalam sistem kekerabatan, menantu dan besan bukanlah orang lain lagi jika telah terjadi pernikahan tetapi sudah selayaknya saudara maka harus disambut baik, dan (b) antar besan harus saling menjaga hubungan baik yang disimbolkan dengan barang bawaan berupa bumbon (bumbu dapur), dan gula bubuk pada saat prosesi pernikahan oleh pihak besan. Gula bermakna aja gela (jangan kecewa) Larangan untuk membenci, dan menerima segala kebaikan dan keburukan besan dan menantu, (c) menghadiri undangan pesta pernikahan.

Sementara untuk nilai religi didasarkan pada klasifikasi yang dibuat oleh Jauhari (2010: 28) yang menyangkut hubungan manusia dengan Tuhan, hubungan manusia dengan masyarakat, dan hubungan manusia dengan diri sendiri. Berikut paparannya.

(1) Hubungan manusia dengan Tuhan terdapat dalam nilai: (a) manusia harus selalu bersyukur Kepada Tuhan Yang Maha Esa, (b) manusia harus selalu bersholawat kepada Nabi, (c) manusia harus bertaubat ke hadirat Tuhan, seperti layaknya kepompong, (d) manusia harus selalu berpegang pada agama agar hidupnya tertata, mengerti halal dan haram), (e) manusia harus pintar namun tetap seimbang dengan kepandaiannya tentang agama.

(2) Hubungan manusia dengan masyarakat terdapat dalam nilai: (a) manusia harus selalu berkumpul dengan orang soleh agar mendapat barokah, (b) larangan agar manusia (muslim) tidak kumpul kebo, (c) hukum-hukum pernikahan dalam Islam, (d) larangan untuk membicarakan aib sesame dan (e) dalam rumah tangga sesuai hukum Islam, perempuan adalah pemegang urusan finansial. Sementara laki-laki berkewajiban menafkahi.

(3) Hubungan manusia dengan diri sendiri terdapat dalam nilai: (a) manusia dilarang menjual makanan atau minuman yang memabukkan, dan (b) setan selalu 
mengganggu manusia dalam beribadah, maka manusia harus selalu waspada.

\section{KESIMPULAN}

Berdasarkan analisis data dan pembahasan dapat disimpulkan beberapa hal berikut.

1) Struktur Cerita dalam Tradisi Lisan Jemblung di Jawa Timur

Berdasarkan analisis terhadap struktur, secara umum alur cerita dalam tradisi lisan jemblung terbagi menjadi empat bagian utama yang saling berkaitan yakni: (a) Keinginan Syeich Abdul Madjid agar tanah Jawa dapat dihuni manusia, dan beliau menyuruh putranya menumbali tanah Jawa, (b) Turunnya Syeich Syubakir ke Jawa untuk menumbali tanah Jawa yang ditentang oleh para lelembut sehingga lelembut meminta bala bantuan ke Tejo Mantri Togog-Bathari Durga, (c) Bathara Kala turun ke Jawa untuk mencari mangsa dan mencabut tumbal Syeich Syubakir, (d) Bathara Kala tidak berhasil menguasai tanah Jawa, dan tanah Jawa dapat dihuni manusia.

Dilihat dari tahapan alur, alur dalam cerita tergolong alur maju karena tahapan-tahapan peristiwa disajikan secara kronologis berurutan. Adapun keterkaitan antara formulasi aktan dengan struktur fungsional adalah korelasi pada tindakan tokoh. Struktur fungsional menjelaskan peranan aktan dalam formulasi aktan, sekaligus menjelaskan alur cerita.

Berdasarkan hasil analisis terhadap latar ditemukan tujuh latar tempat yang tidak kesemuanya merupakan latar fisik yang dapat ditemukan di dunia nyata. Latar fisik yang dapat ditemukan di dunia nyata yakni Blitar, Gedangan-Sidoarjo, Surabaya, dan desa Branggahan-Ngadiluwih. Kesemuanya merupakan daerah-daerah yang secara administratif berada di propinsi Jawa Timur. Sementara Pondok Ngarum Stambul, Paseban Ganda Mayit, dan Suralaya merupakan tempat yang tidak dapat dijumpai dalam kehidupan nyata. Besar kemungkinannya tempat-tempat tersebut hanyalah rekaan dalang semata.

Berdasarkan analisis terhadap ketiga aspek di atas, secara umum dapat disimpulkan bahwa struktur cerita dalam pertunjukan jemblung merupakan teks drama. Deretan peristiwa dalam cerita disampaikan oleh dalang dengan cara monolog, diselingi ko-teks pertunjukan.

Pada penelitian ini ditemukan 12 tokoh. Keduabelas tokoh tersebut berdasarkan fungsinya menurut Sudjiman (1991: 17) terbagi dalam tokoh sentral dan tokoh bawahan. Selain tokoh sentral dan tokoh bawahan terdapat pelaku lataran, yakni pelaku yang menjadi bagian dari latar.

Berdasarkan peranannya dalam alur, Syeich Syubakir dan Bathara Kala merupakan tokoh sentral yang berperan sebagai pelaku utama atau penggerak cerita. Setiap tindakan yang dilakuka oleh Syeich Syubakir dan Bathara Kala mempengaruhi cerita. Tindakan Syubakir menumbali tanah Jawa mempengaruhi kehidupan para lelembut di tanah Jawa, dan juga memancing kedatangan Bathara Kala untuk memangsa manusia yang ada di tanah Jawa. Tindakan Bathara Kala turun ke tanah Jawa dan mencari mangsa manusia mempengaruhi stabilitas kehidupan manusia di tanah Jawa. Dapat diasumsikan bahwa tanpa adanya Syeich Syubakir dan Bathara Kala maka cerita akan menjadi beku, sehingga keduanya disebut sebagai tokoh sentral.

2) Konteks penuturan tradisi lisan Jemblung di Jawa Timur

Dilihat dari konteks budaya pertunjukan jemblung dilaksanakan dalam berbagai acara adat seperti hajatan pernikahan, hajatan khitanan, bersih desa, perayaan Agustusan, tasyakuran, dst. Pada penelitian ini pertunjukan dilaksanakan pada acara pernikahan. Termasuk salah satu rangkaian acara ruwatan pernikahan. 
Pertunjukan jemblung dipilih sebagai hiburan karena dianggap cukup terjangkau dibandingkan pertunjukan lain yang biasa digunakan dalam perayaan pernikahan, seperti pertunjukan wayang kulit. Terutama bagi penanggap yang berasal dari kalangan sosial masyarakat menengah ke bawah. Selain itu, pertunjukan jemblung dipandang sebagai pertunjukan yang sangat merakyat terutama dalam aspek bahasa sehingga dapat dijangkau dan menghibur semua kalangan terutama kalangan awam.

Berdasarkan analisis terhadap konteks sosial yang telah dipaparkan pada bagian deskripsi data, dapat disimpulkan bahwa tradisi lisan jemblung dalam penelitian ini dimainkan oleh kelompok kesenian jemblung "Sadat Sawedhar" dari desa Tunjungan, kecamatan Udanawu, Kabupaten Blitar. Pemain kesenian ini terdiri dari berbagai profesi yang heterogen, namun sebagian besar bermata pencaharian sebagai petani sebagai mata pencaharian utama. Usia pemain dikelompokkan menajdi dua, yakni golongan tua dan golongan muda. Golongan tua menduduki peran sebagai pemain inti, sementara golongan muda yang jumlahnya relatif lebih sedikit menduduki peran pemain tambahan. Hal ini dapat dijadikan alasan betapa pentingnya regenerasi pemain kesenian jemblung.

Dapat disimpulkan bahwa tradisi lisan jemblung hidup dalam konteks sosial masyarakat Jawa Timur dengan berbagai latar belakang yang berbeda. Baik dari aspek usia, tingkat pendidikan, dan latar belakang sosial lainnya. Dengan kata lain, jemblung dapat dinikmati oleh semua kalangan, baik anakanak maupun dewasa, baik kalangan mampu maupun yang kurang mampu. Adapun karena jemblung merupakan kesenian Jawa Islami, maka sasarannya memang untuk orang Islam karena dari segi isi didominasi oleh ajaranajaran Islam. Meski tidak ada larangan bagi agama lain untuk menyaksikan atau menanggap kesenian ini.
Analisis terhadap konteks sosial berdasarkan pada teori Sibarani (2012:325) yang mengacu pada waktu, tempat, dan penggunaan teks. Berdasarkan analisis terhadap konteks situasi dapat diketahui bahwa pertunjukan jemblung ini terorganisasi dan terencana. Pertunjukan dalam situasi informal dan dilaksanakan pada malam hari. Di rumah Ibu Poniyem dalam rangka berbahagia meruwat putra semata wayangnya yang sedang melangsungkan pernikahan.

Analisis terhadap konteks Ideologi berdasarkan pada teori Sibarani (2012) yang mengacu pada kekuasaan atau kekuatan yang mendominasi isi teks. Pertunjukan jemblung merupakan kesenian Jawa Islami yang bermuatan hukum-hukum Islam. Dakwah yang dikemas dalam kesenian. Ideologi religi yang melatarbelakangi tentu saja adalah agama Islam dalam konteks budaya Jawa. Sesuai keseharian hidup orang Jawa.

3) Ko-teks dalam tradisi lisan Jemblung di Jawa Timur

Analisis Ko-teks dalam tradisi lisan jemblung mengacu pada Sibarani (2012) yang mengklasifikasikan ko-teks tradisi lisan dalam konsep antropolinguistik, meliputi: (a) deskripsi paralinguistik, (b) gestur (c) penjagaan antarpelaku, dan (d) Unsur material: pakaian, penataan lokasi dan dekorasi, penggunaan properti dan fungsinya.

Deskripsi mengenai penjagaan jarak antar pelaku memberikan memberikan interpretasi bahwa antarpelaku (pemain) memiliki blocking yang jelas. Analisis unsur material dalam pertunjukan jemblung pada penelitian ini meliputi: pakaian, penataan lokasi dan dekorasi, penggunaan properti dan fungsinya.

Beberapa properti tambahan digunakan selain memiliki fungsi tertentu juga memiliki makna tertentu. Alat musik inti yang berjumlah enam buah memiliki makna filosofis tertentu sehingga tidak hanya berfungsi sebagai alat musik saja. Begitu juga dengan penggunaan kupat luwar yang bermakna simbolik 
sebagai media pelepas segala kesedihan dan kecelakaan. Wayang yang digunakan hampir sama fungsinya dengan wayang purwa, yakni sebagai alat peraga. Meski jumlah wayang tidak selengkap seperti dalam wayang purwa.

Dapat disimpulkan bahwa ko-teks sangat mendukung jalannya pertunjukan dalam membangun suasana dan mempertegas pesan yang diusung dalam pertunjukan.

4) Proses pewarisan tradisi lisan Jemblung di Jawa Timur.

Analisis terhadap proses pewarisan dalam tradisi lisan jemblung ini dibagi menjadi dua yakni proses menjadi pemain dan proses penciptaan cerita. Proses menjadi pemain dalam pertunjukan Jemblung dapat dilakukan secara vertikal maupun horizontal. Proses menjadi pemain pada penelitian ini pun demikian, beberapa pemain mengalami proses vertikal, dan sebagian lain mengalami proses horizontal. Secara vertical artinya berbeda generasi, secara horizontal artinya masih dalam satu generasi.

Sementara proses penciptaan cerita oleh dalang pada zaman dahulu berdasarkan cerita Menak, tetapi seiring perkembangan zaman cerita bisa bersumber dari babad atau sesuai konteks pertunjukan yang merupakan kreasi dalang.

5) Fungsi tradisi lisan jemblung di Jawa Timur

Berdasarkan temuan di lapangan, dapat disimpulkan fungsi tradisi lisan jemblung sebagai berikut: (a) alat pengesahan kebudayaan, (b) pemaksa berlakunya norma di masyarakat, (c) alat pendidikan, dan (d) hiburan, (e) media dakwah, (f) media propaganda tematik, dan $(\mathrm{g})$ ritual.

6) Nilai-nilai yang terkandung dalam tradisi lisan jemblung di Jawa Timur

Berdasarkan analisis secara keseluruhan, ditemukan nilai budaya dan nilai religius yang paling dominan dalam tradisi lisan jemblung. Nilai-nilai budaya yang ditemukan jika dikaitkan dengan kerangka Kluckhohn mengenai nilai budaya, maka nilai-nilai budaya dalam jemblung juga mencakup kategori-kategori sebagai berikut: Masalah universal mengenai hakekat hidup yang tercermin dalam nilai-nilai sebagai berikut: (a) tradisi ruwatan sebagi pembersih diri, (b) konsep bala kiwa bala tengen dalam wayang ( golongan kanan dan golongan kiri), dan (c) peribahasa bathok bolu isi madu yang merupakan sifat dari tokoh Semar; (2) Hakikat karya dan etos kerja, tercermin dalam nilai-nilai sebagai berikut: (a) harapan agar kedua mempelai kuat dalam mengarungi rumah tangga disimbolkan dalam kuwade (pelaminan), (b) ritual melempar daun sirih pada prosesi pernikahan bermakna bahwa daun sirih baik terjatuh dengan telentang atau telungkup, jika digigit akan sama saja rasanya dan nilai dalam prosesi menuangkan tilam lupus oleh pengantin laki-laki ke pangkuan pengantin perempuan pada saat temu pengantin, yang dipaparkan maknanya oleh dalang sebagai perjanjian soal nafkah antara suami dengan istri; (3) Persepsi manusia tentang waktu, tercermin dalam nilai pamali (larangan) memotong bambu di tengah hari; (4) Pandangan manusia terhadap alam tercermin dalam kewajiban mengikat bambu yang telah dipotong-potong karena akan menjadi sandungan Bathara Kala; dan (5) Hakikat hubungan manusia dengan sesamanya tercermin dalam nilai sebagai berikut: (a) ritual unik ketika ada orang yang melahirkan, dalam sistem kekerabatan, menantu dan besan bukanlah orang lain lagi jika telah terjadi pernikahan tetapi sudah selayaknya saudara maka harus disambut baik, dan (b) antar besan harus saling menjaga hubungan baik yang disimbolkan dengan barang bawaan berupa bumbon (bumbu dapur), dan gula bubuk pada saat prosesi pernikahan oleh pihak besan. Gula bermakna aja gela (jangan kecewa) Larangan untuk membenci, dan menerima segala kebaikan dan keburukan besan dan menantu. 
Nilai-nilai religius yang ditemukan sebagai berikut (1) Manusia harus selalu bersyukur Kepada Tuhan Yang Maha Esa, (2) Manusia harus selalu bersholawat kepada Nabi, (3) Manusia harus selalu berkumpul dengan orang soleh agar mendapat barokah, (4) Manusia harus selalu berpegang pada agama agar hidupnya tertata, mengerti halal dan haram, (5) Manusia harus pintar namun tetap seimbang dengan kepandaiannya tentang agama, (6) Manusia dilarang menjual makanan atau minuman yang memabukkan, (7) Larangan agar manusia (muslim) tidak kumpul kebo, (8) Hukum-hukum pernikahan dalam Islam, (9) Larangan untuk membicarakan aib sesame, (10) Manusia harus bertaubat ke hadirat Tuhan, seperti layaknya kepompong, (11) Setan selalu mengganggu manusia dalam beribadah, maka manusia harus selalu waspada, dan (12) Dalam rumah tangga sesuai hukum Islam, perempuan adalah pemegang urusan finansial. Sementara laki-laki berkewajiban menafkahi.

7) Ancangan model revitalisasi tradisi lisan Jemblung di Jawa Timur

Ancangan model revitalisasi dalam penelitian ini meliputi ancangan revitalisasi di pendidikan formal dan pendidikan nonformal. Ancangan revitalisasi di pendidikan formal sebagai berikut : Kegiatan ekstrakurikuler Jemblung di sekolah-sekolah menengah di seluruh Jawa Timur, dan alih wahana pertunjukan Jemblung sebagai alternatif bahan ajar pembelajaran bahasa di sekolah. Adapun ancangan di pendidikan nonformal adalah: pementasan pertunjukan Jemblung berskala regional/nasional dan ancangan pembuatan buku tentang tradisi Lisan Jemblung Jawa Timur.

\section{DAFTAR PUSTAKA}

Ali, M.S. (2009) Transformasi Pertunjukan Kesenian Jemblung "Putra Budaya" di dusun Kemuning Kelurahan Lirboyo Kecamatan Mojoroto Kota Kediri. Skripsi, Universitas
Negeri Malang.

Darni. (2010) Modifikasi Seni Jemblung di Ponorogo. Jurnal seni budaya Jawa Timur vol III, hlm $1-16$.

Effendi, R. (2010) Bahasa dalam wayang Jemblung di Kabupaten Tulungagung. Skripsi, Universitas Negeri Malang.

Finnegan, R. (1989) Oral Traditiions and The Verbal Arts. London and New York: Rouletdge.

Hutomo,S.S. (1991) Mutiara yang Terlupakan. Jawa Timur: HISKI.

Hutomo,S.S (1987) Cerita Kentrung Sarahwulan di Tuban. Disertasi, Universitas Indonesia.

Jauhari, H. (2010) Nilai Religius dalam Karya Sastra. Bandung: Arfino Raya.

Koentjaraningrat. (1994) Kebudayaan Jawa. Jakarta: Balai Pustaka.

Prabowo. (2012) Seni Jemblung Murtadho dari Desa Tunjung Kajian Etnomusikologi. Skripsi, Universitas Negeri Malang.

Rahmawati. (2008) Nilai-Nilai Pembangunan Masyarakat Desa Dalam Kesenian Jemblung Di Desa Tunjung Kecamatan Udanawu Kabupaten Blitar. Skripsi, Universitas Negeri Malang.

Saptaria, R.E. (2006) Acting handbook. Bandung: Rekayasa sains.

Sibarani, R.(2010) Kearifan Lokal, Hakikat, Peran, dan Metode Tradisi Lisan. Jakarta: ATL.

Sims, M.C \&Stephens,M. (2005) Living Folklore: An Introduction to the Study of People and Their Traditions.Utah: Utah State University.

Stanton, R .(2007) Teori Fiksi. Yogyakarta: Pustaka Pelajar.

Sudjiman, P.(1991) Memahami Cerita Rekaan. Bandung: Remaja Rosda Karya.

Sukatman. (2011) Butir-Butir Tradisi Lisan Indonesia. Yogyakarta: LaksBang Pressindo.

Sugiyono.(2010) Metode Penelitian Kuantitatif, Kualitatif, dan R\&D. Bandung: Alfabeta.

Taum, Y.Y. (2011) Studi Sastra Lisan (Sejarah, Teori, Metode, dan Pendekatan Disertai Contoh dan Penerapannya). Yogyakarta: Lamalera. 